\title{
PEMBUATAN APLIKASI WEB PENCARIAN JASA PEMBANTU RUMAH TANGGA (PRT) DIKOTA TERNATE
}

\section{WEB APPLICATION CREATION SEARCH HOUSEKEEPER SERVICE IN TERNATE CITY}

\author{
Sucianti Saiful ${ }^{1}$, Arisandy Ambarita ${ }^{2}$ \\ Program Studi Manajemen Informatika \\ Politeknik Sains dan Teknologi Wiratama Maluku Utara \\ Suciantisaifu106@gmail.com
}

\begin{abstract}
Abstrak
Dinas Tenaga Kerja merupakan instansi pemerintah yang terdapat di kota ternate, yang pada saat ini mengalami kesulitan dalam mencari informasi tentang pembantu rumah tangga (PRT) karena keterbatasan informasi yang tersebar sehingga calon majikan yang ingin mencari dan menyewa pembantu rumah tangga (PRT) harus bertanya-tanya informasi tentang pembantu tersebut pada teman atau keluarga hingga bertanya Infromasi pada kantor Dinas Tenaga Kerja Kota Ternate tersebut. Penilitian ini bertujuan untuk membuat Aplikasi Web Pencarian Jasa Pembantu Rumah Tangga (PRT), Metode Analisis dan Pengembangan Sistem menggunakan Model Driven Analisis Berorientasi Objek serta Pengembangannya menggunakan metode sekuensial linier (Waterfall), Sistem ini dirancang dengan Alat bantu UML (Unified Modeling Languange) dan dibuat menggunakan bahasa Pemrograman HTML, CSS, PHP serta database MySQL, dengan adanya sistem ini diharapkan dapat memberikan informasi pada Dinas Tenaga Kerja serta membantu calon majikan dalam mengetahui informasi calon pembantu rumah tangga tanpa harus bertanya-tanya lagi ke teman atau keluarga, cukup dengan melihat dan melakukan pemesanan melalui sistem tersebut.
\end{abstract}

Kata Kunci: Aplikasi Web, Jasa, Pembantu Rumah Tangga

\begin{abstract}
The Department of Labor is a Government agency located in the city of ternate, which at the moment have difficulty in finding information about the housemaid because of the limited information that is scattered so that a prospective employer looking to hire a housekeeper have to wonder information about these helpers on your friends or family to ask Information on the office of
\end{abstract}


the Department of Labor of the City. This research aims to make Web Application Search Services Housekeeper, Methods of Analysis and Systems Development using Model Driven Object Oriented Analysis and Development using the method of linear sequential (Waterfall), the System is designed with Tools UML (Unified Modeling Languange) and created using the Programming languages HTML, CSS, PHP as well as MySQL database, with this system is expected to provide information on the Department of Labor as well as help the prospective employer in knowing the information prospective housekeeper without having to wonder anymore to friends or family, just look at it and do a booking through the system.

\section{Keywords: Web Aplication, Service, Housekeeper}

\section{PENDAHULUAN}

Teknologi informasi saat ini mengalami perkembangan yang sangat pesat. Salah satu teknologi informasi yang berkembang pesat adalah internet. Internet banyak dimanfaatkan untuk bertukar informasi di dalam dunia maya, dengan menggunakan teknologi internet orang dapat mengakses informasi dimana saja dan kapan saja, tanpa ada batasan waktu. (Ilmi \& Qariah 2016)

Manfaat internet yang sangat besar tersebut tentunya memudahkan semua orang untuk mengakses berbagai informasi dengan cepat dan mudah. Hal tersebut berkaitan bagi orang-orang yang memiliki aktivitas tinggi termasuk wanita karir. Rutinitas harian yang cukup padat membuat ibu rumah tangga khususnya wanita karir tidak bisa mengerjakan semua pekerjaan rumah tangga sendiri, dengan adanya runtinitas aktifitas wanita karir yang sibuk bekerja sehingga pekerjaan rumah tidak dapat dilakukan dan tidak memiliki waktu dalam mencari informasi tentang jasa pembantu rumah

tangga seperti halnya pada dinas tenaga kerja.

Dinas Tenaga Kerja merupakan instansi pemerintah yang terdapat di kota ternate, yang pada saat ini mengalami kesulitan dalam mencari informasi tentang pembantu rumah tangga (PRT) karena keterbatasan informasi yang tersebar sehingga calon majikan yang ingin mencari dan menyewa pembantu rumah tangga (PRT) harus bertanya-tanya informasi tentang pembantu tersebut pada teman atau keluarga hingga bertanya Infromasi pada kantor Dinas Tenaga Kerja Kota tersebut., sehingga mempersulit Majikan serta Instansi terkait dalam mencari informasi pembantu rumah tangga yang ada dikota ternate. Berdasarkan uraian masalah sebelumya maka diusulkan Aplikasi Web Pencarian Jasa Pembantu Rumah Tangga di Kota Ternate

\section{Rumusan Masalah}

Berdasarkan latar belakang sebelumnya maka dapat di 
identifikasikan permasalahan yang diambil sebagai topik dari penelitian ini adalah bagaimana merancang aplikasi web pencarian jasa pembantu rumah tangga (PRT) di Kota Ternate?

\section{LANDASAN TEORI}

\section{Pengertian Sistem}

Menurut (McLeod dalam Yakub, 2012) mendefiniskan sistem adalah sekelompok elemen-elemen yang terintegrasi dengan tujuan yang sama untuk mencapai tujuan. Sistem juga merupakan suatu jaringan kerja dari prosedur - prosedur yang saling berhubungan, terkumpul bersama-sama untuk melakukan suatu kegiatan atau untuk tujuan tertentu.

\section{Sistem Informasi}

Menurut Sutarman (2012) sistem informasi adalah sistem yang dapat didefinisikan dengan mengumpulkan, memproses, menyimpan, menganalisis, menyebarkan informasi untuk tujuan tertentu. Seperti sistem lainnya, sebuah sistem informasi terdiri atas input (data, instruksi) dan output (laporan, kalkulasi).

\section{Pembantu Rumah Tangga}

Konsep profesi merupakan suatu jenis pekerjaan yang membutuhkan keahlian, loyalitas dan intensitas dalam menjalankan tugasnya dan bersifat individual (pekerjaan) (Soenyoto, 2008), sejalan dengan hal tersebut maka pembantu rumah tangga masuk dalam kategori sebagai suatu profesi.

\section{Pengertian Web}

Menurut Ardhana (2012), website adalah suatu layanan sajian informasi yang menggunakan konsep hyperlink, yang memudahkan surfer (sebutan para pemakai komputer yang melakukan browsing atau penelusuran informasi melalui internet).

\section{Pengertian PHP}

PHP adalah pemrograman (interpreter) adalah proses penerjemahan baris sumber menjadi kode mesin yang dimengerti komputer secara langsung pada saat baris kode dijalankan (Sibero 2012).

Menurut Betha Sidik (2014) Xampp merupakan paket server web PHP dan database MySQL. Yang paling populer di kalangan pengembangan web menggunakan PHP dan MySQL sebagai Databasenya.

\section{Pengertian MySQL}

MySQL merupakan software database yang termasuk paling popular di lingkungan Linux, kepopuleran ini karena ditunjang karena performansi query dari databasenya yang saat itu bisa dikatakan paling cepat dan jarang bermasalah (Sidik, 2012).

\section{Pengertian Unified Modeling Languange ( UML)}

Unified Modeling Language (UML) adalah salah satu standar bahasa yang banyak digunakan di dunia industri untuk mendefinisikan requirement, membuat analisis dan desain, serta menggambarkan arsitektur 
dalam pemrograman berorientasi objek. $U M L$ merupakan bahasa visual untuk pemodelan dan komunikasi mengenai sebuah sistem dengan menggunakan diagram dan teks-teks pendukung.

\section{Use Case Diagram}

Rosa dan M. Shalahudin (2014:155), use case atau diagram use case merupakan pemodelan untuk kelakuan (behavior) sistem informasi yang akan dibuat.

Diagram aktivitas atau activity diagram menggambarkan workflow (aliran kerja) atau aktivitas dari sebuah sistem atau proses bisnis atau menu yang ada pada perangkat lunak.

\section{METODE PENELITIAN}

1. Angket Adalah teknik pengumpulan data yang dilakukan dengan cara memberikan seperangkat pertanyaan atau pernyataan kepada orang lain yang dijadikan responden untuk dijawabnya.

2. Observasi adalah suatu metode pengumpulan data dimana penelitian dilakukan secara langsung terhadap objek yang akan diteliti.

\section{Metode Analisis dan Pengembangan Sistem}

Metode analisis sistem yang digunakan adalah Model Driven Analisis Berorientasi Objek yang bisa disebut Model OOA (Object Oriented Analisys and Design) yaitu model gambar-gambar yang mengilustrasikan objek-objek sistem dari berbagai perspektif seperti struktur, perilaku dan interasi antar objek. Alat bantu (tools) yang digunakan adalah UML (Unified Modeling Languange).

Metode pengembangan pembuatan aplikasi web pencarian jasa pembantu rumah tangga ini menggunakan metode sekuensial linier (waterfall). Metode waterfall merupakan metode pengembangan perangkat lunak yang sistematik dan sekuensial yang mulai pada tingkat dan kemajuan sistem sampai pada analisis,desain,kode,test dan pemeliharaan.

Berikut merupakan tahapan penelitian dalam metode pengembangan sistem :

1. Analisis

Pada tahap ini peneliti menganalisa kebutuhan sistem. dimana mengumpulkan data dan melakukan sebuah penelitian. Tahapan inilah yang akan menghasilkan dokumen atau bisa dikatakan data yang berhubungan dengan keinginan user dalam pembuatan sistem.

2. Perancangan

Pada tahap ini peneliti merancang sistem dengan menggunakan Model Driven pendekatan Analisis Berorientasi Objek yaitu menggambar Diagram UML sistem yang berjalan dan sistem yang diusulkan menggunakan alat bantu Activity Diagram, selanjutnya membuat diagram rincian Use Case, Sequance Diagram, Class 
Diagram dan Rancangan output tampilan menu.

3. Implementasi

Pada tahap ini peneliti menerapkan sistem sesudah kode desain aplikasi dimasukkan dengan bahasa pemrograman html, php, css, server, xammp dan database $M y S Q L$.

4. Pengujian (test) dan pemeliharaan Pada tahap ini peneliti penguji menu-menu yang ada pada sistem dengan menggunakan metode blackbox dan manajemen sistem.

\section{Analisys Sistem yang Berjalan}

Sistem yang berjalan tentang pencarian jasa pembantu rumah tangga dikota ternate dapat di lihat pada gambar berikut ini.

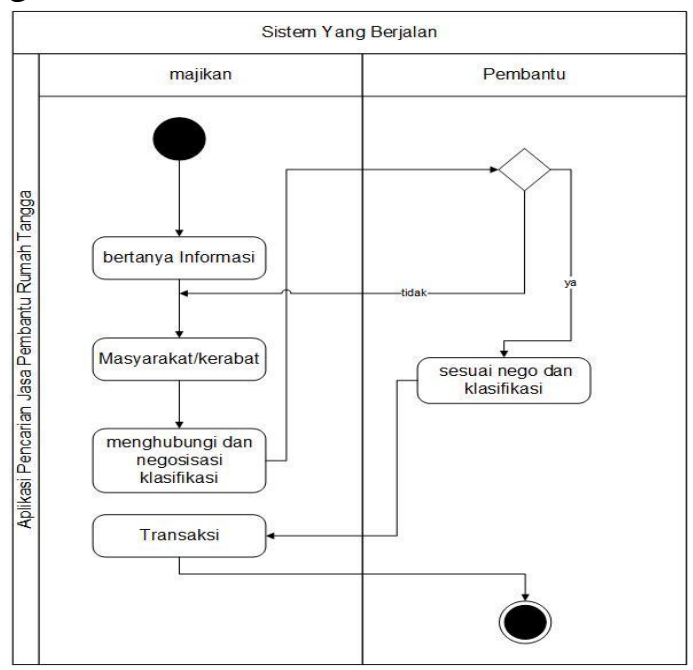

Gambar 1: Sistem Yang Berjalan

\section{Analisys Sistem yang Diusulkan}

Sistem yang diusulkan peneliti berdasarkan identifikasi masalah pada sistem yang berjalan.

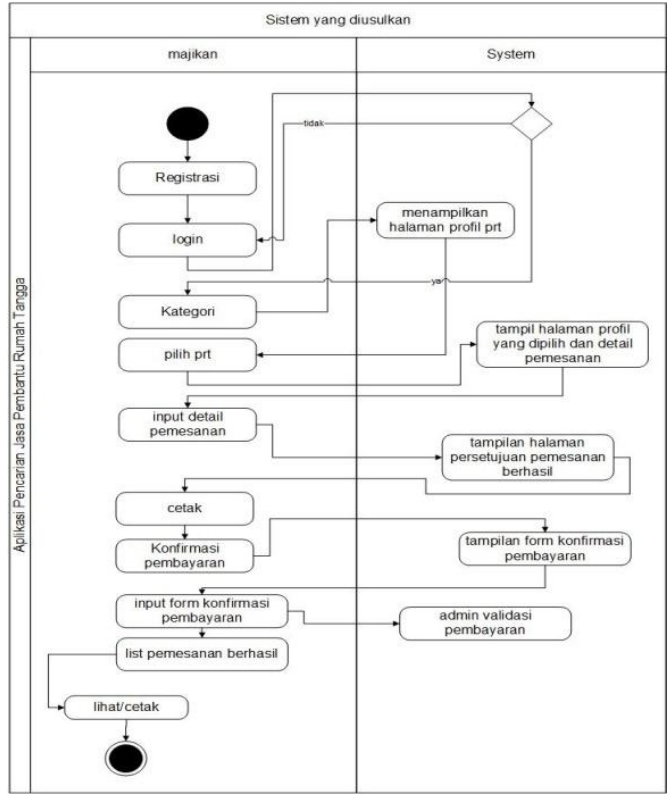

Gambar 2: Sistem Yang Diusulkan

\section{Kebutuhan Fungsional}

Kebutuhan fungsional adalah kebutuhan - kebutuhan yang memiliki keterkaitan langsung dengan sistem. Kebutuhan fungsional dari sistem ini adalah :

1. Kebutuhan Pengguna

a. Mendapatakan informasi data pembantu rumah tangga

b. Mendapatkan informasi tentang persediaan pembantu rumah tangga

2. Kebutuhan Administrator

a. Melakukan Login ke system

b. Mengelola data-data pemesanan jasa pembantu rumah tangga

\section{Kebutuhan Non Fungsional}

Kebutuhan non-fungsional adalah kebutuhan yang tidak secara langsung 
terkait dengan fitur tertentu di dalam system, antara lain :

1. Kebutuhan Perangkat Keras
a. Laptop Acer One z1402
b. Printer Canon MP230
c. Flashdisk

2. Kebutuhan Perangkat Lunak

a. Sistem Operasi windows 7 Ultimate 32 Bit

b. Mysql sebagai media database

c. Microsoft office word 2007 Sebagai pembuatan hasil laporan

d. Microsoft Visio 2007 untuk membuat gambar alur program.

e. Notepad++ digunakan untuk editor dalam merancang bahasa pemrograman website.

f. Xampp Untuk Media Server

g. Pemograman menggunakan bahasa HTML, PHP, CSS, dan MySQL

\section{PERANCANGAN SISTEM}

\section{Use Cace Diagram}

Use Case adalah abstraksi dari sebuah interaksi antara sistem dan actor. Berikut ini adalah gambar Use Case Sistem yang diusulkan:

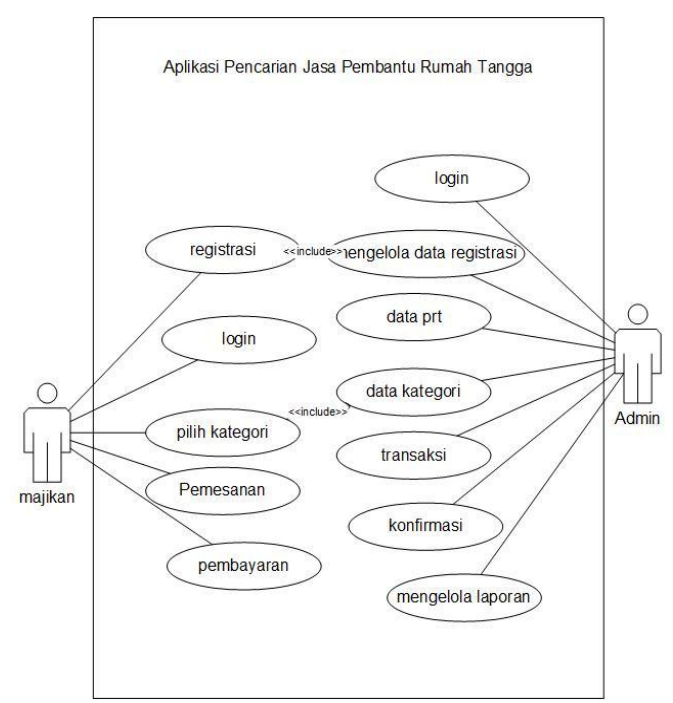

Gambar 3: Use Case Sistem Usulan

\section{Sequance Diagram}

Sequence diagram adalah suatu diagram yang menggambarkan interaksi antar obyek dan mengindikasikan komunikasi diantara obyek-obyek tersebut.

\section{Sequance Menu Utama Registrasi Majikan}

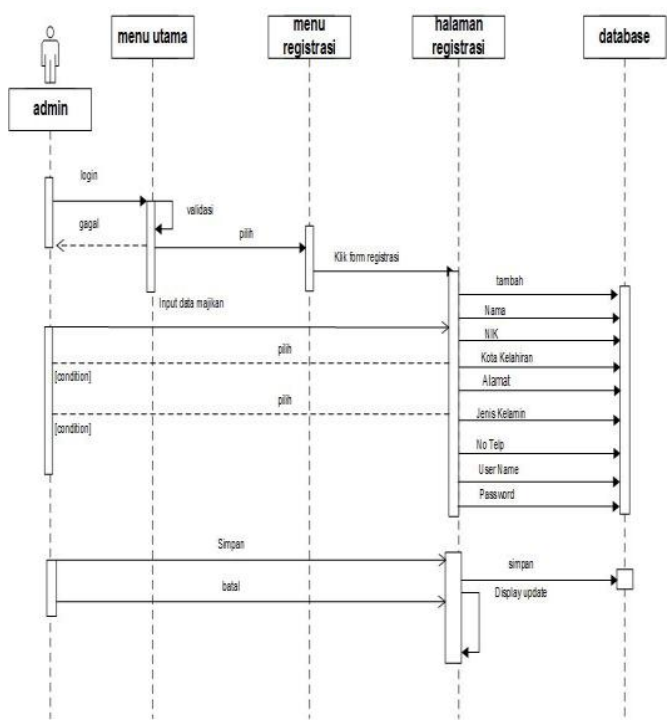

Gambar 4: Sequance Menu Utama Registrasi Majikan 
Sequance Login Admin dan Majikan

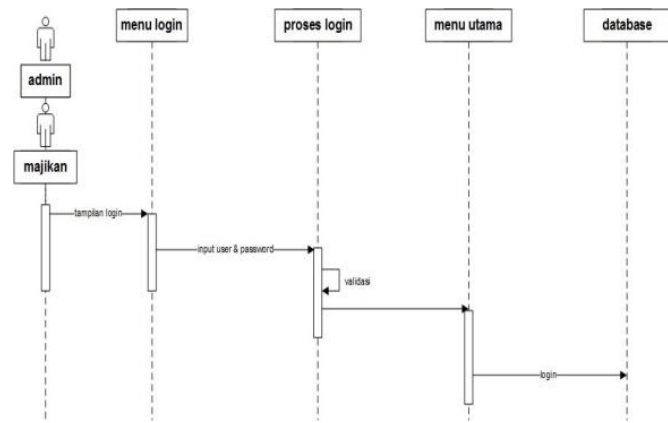

Gambar 5: Sequance Login Admin dan Majikan

\section{Sequance Admin Kelola Data}

\section{Registrasi PRT}

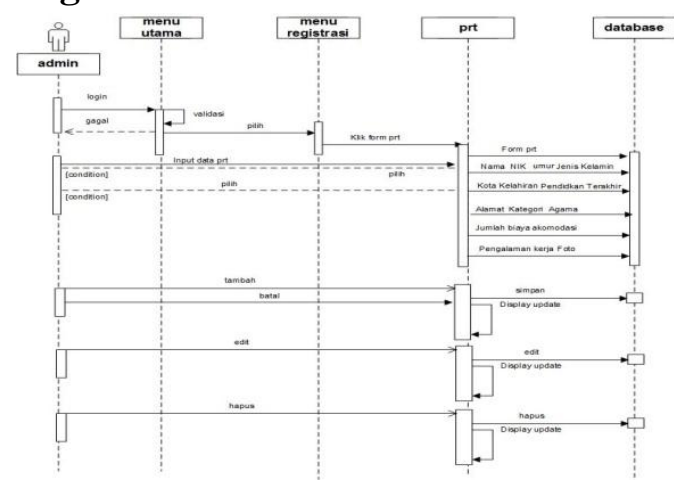

Gambar 6: Sequance Admin Kelola

Data Registrasi PRT

\section{Sequance Admin Kelola Data}

\section{Registrasi Majikan}

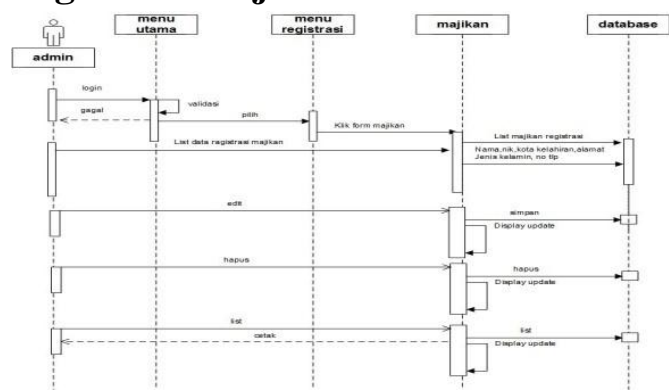

Gambar 7: Sequance Admin Kelola Data Registrasi Majikan
Sequance Admin Kelola Data Kategori

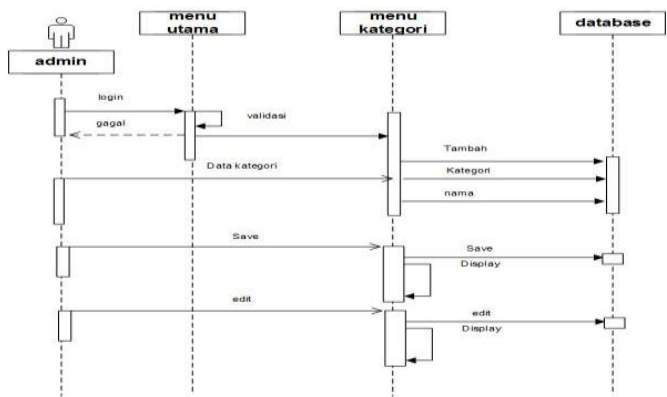

Gambar 8: Sequance Admin Kelola Data Kategori

\section{Sequance Admin Kelola Data} Transaksi Konfirmasi Pemesanan

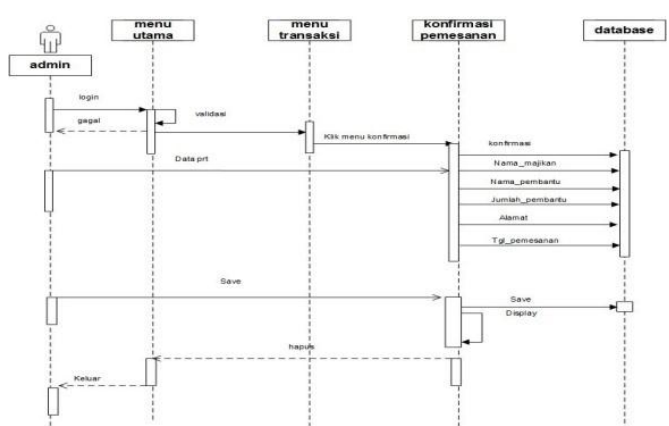

Gambar 9: Sequance Admin Kelola Data Transaksi Konfirmasi Pemesanan

\section{Sequance Admin Kelola Data} Transaksi List Pemesanan

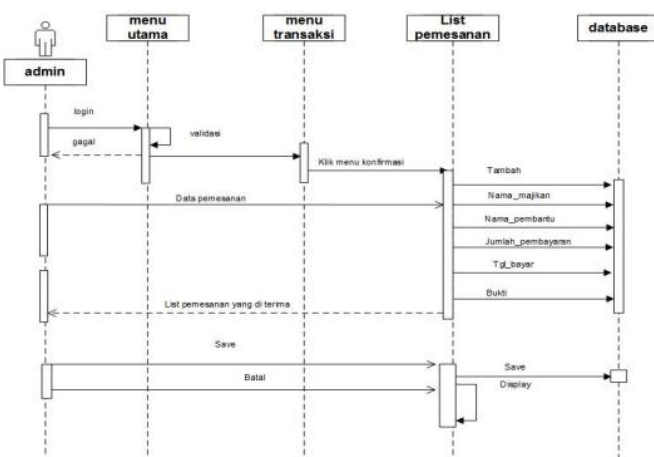

Gambar 10: Sequance Admin Kelola

Data Transaksi List

Pemesanan 
Sequance Admin Kelola Data

\section{Laporan}

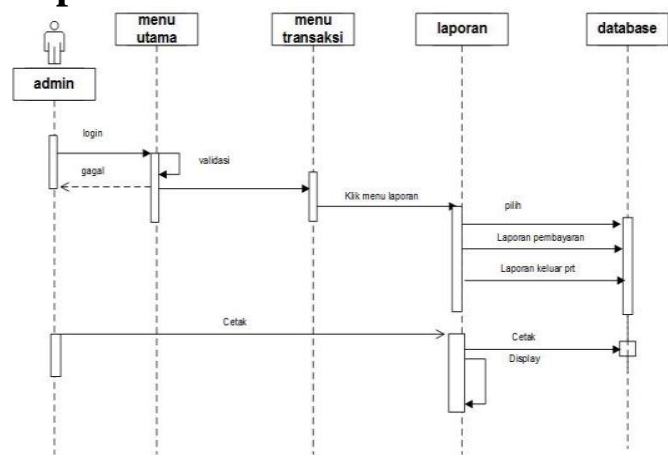

Gambar 11: Sequance Admin Kelola Data Laporan

\section{Sequance Admin Kelola Data User}

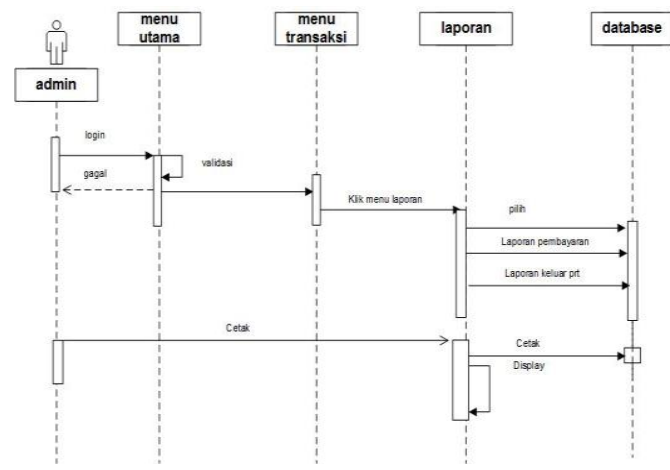

Gambar 12: Sequance Admin Kelola Data User

\section{Sequance Menu Utama Majikan}

\section{Registrasi}

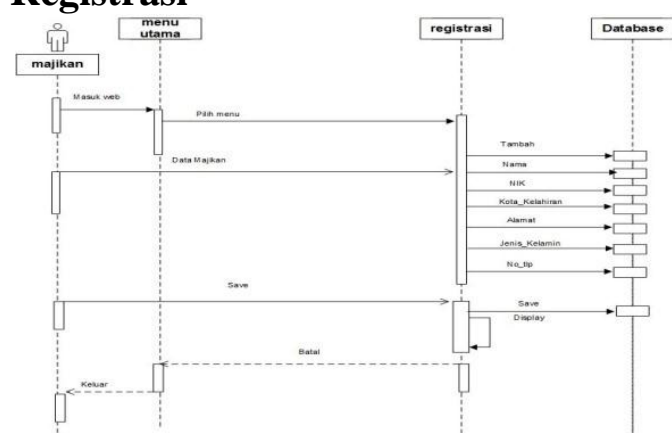

Gambar 13: Sequance Menu Utama

Majikan Registrasi
Sequance Menu Majikan Pesan prt Pada Menu Kategori

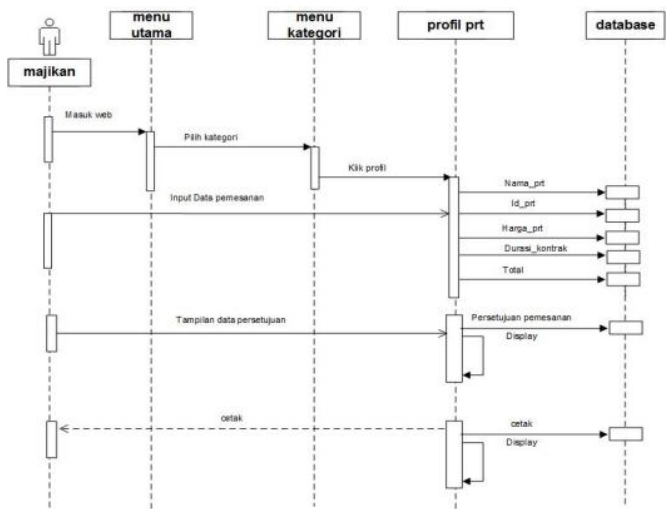

Gambar 14: Sequance Menu Majikan Pesan Prt Pada Menu Kategori

Sequance Menu Majikan Konfirmasi Pembayaran

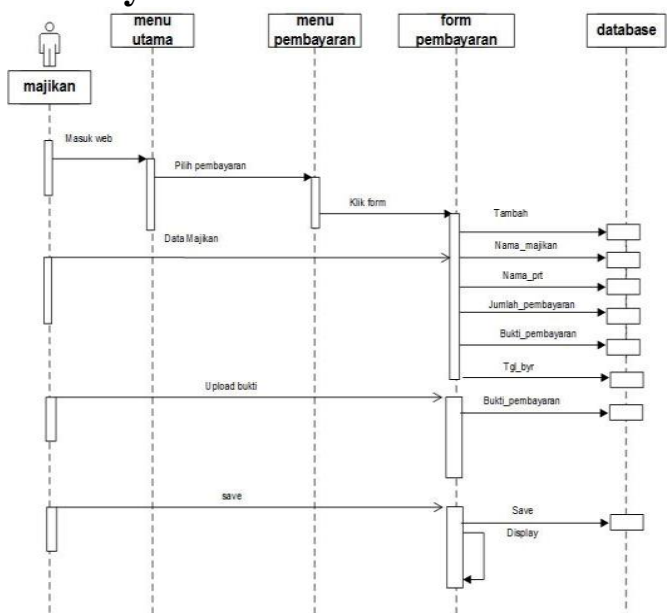

Gambar 15: Sequance Menu Majikan Konfirmasi Pembayaran

\section{Class Diagram}

Class Diagram merupakan Diagram relasi pada Database sistem yang digunakan sebagai petunjuk pada database menu saat sistem dijalankan 


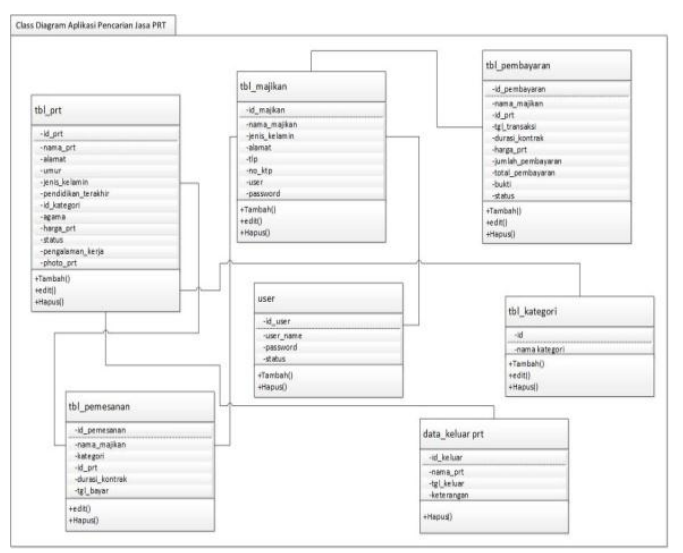

Gambar 16: Class Diagram

\section{Rancangan Struktur Tabel Sistem Rancangan Tabel User}

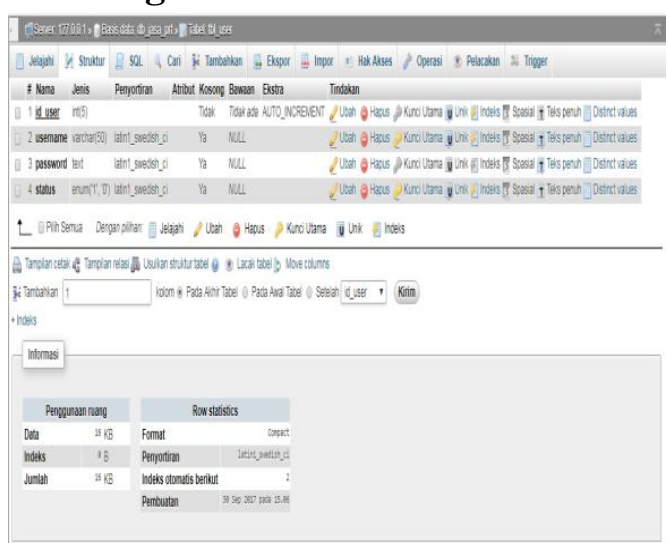

Gambar 17: Tabel User

\section{Rancangan Tabel Majikan}

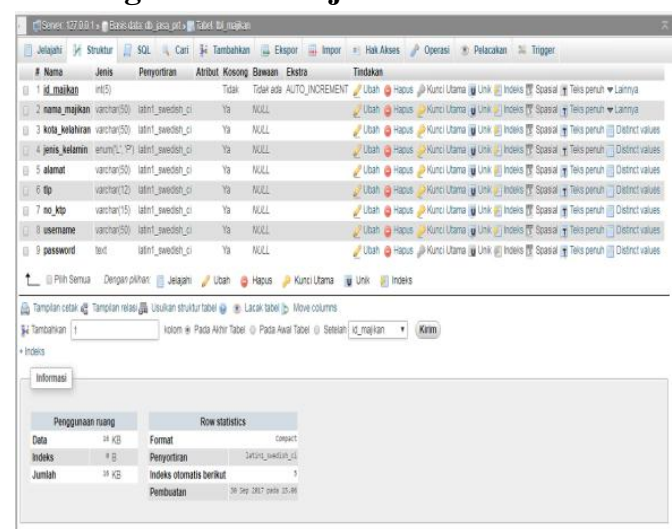

Gambar 18: Tabel Majikan

\section{Rancangan Tabel Prt}

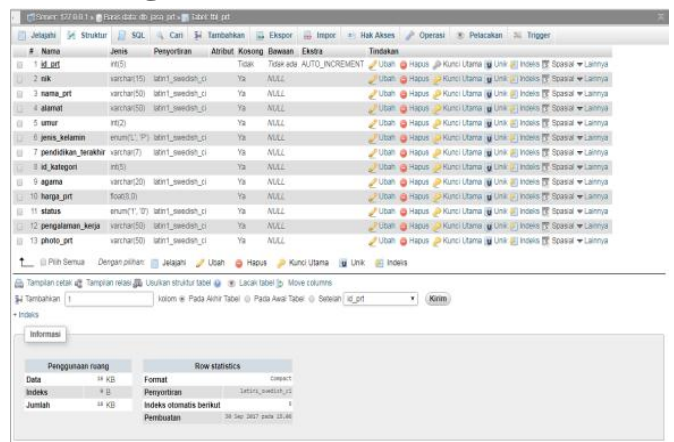

Gambar 19: Tabel Pembantu Rumah Tangga

\section{Rancangan Tabel Kategori}

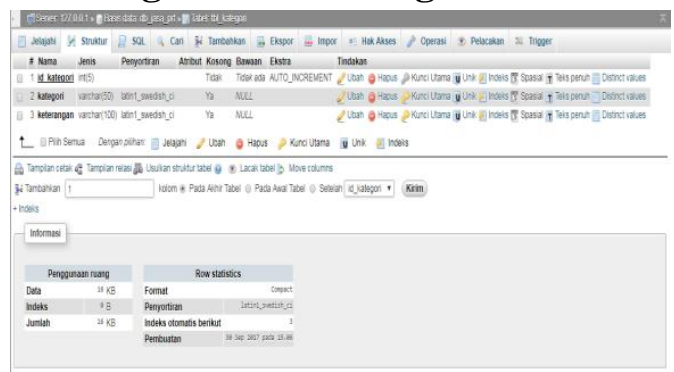

Gambar 20: Tabel Kategori

\section{Rancangan Tabel Pembayaran}

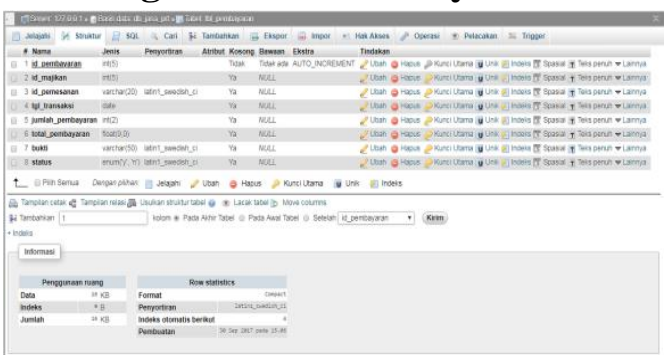

Gambar 21: Tabel Pembayaran

\section{Rancangan Tabel Pemesanan}

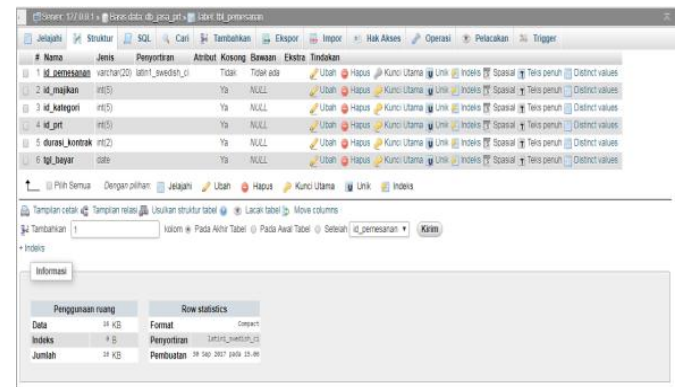

Gambar 22: Tabel Pemesanan 


\section{IMPLEMENTASI/PENGUJIAN SISTEM}

\section{Halaman Utama}

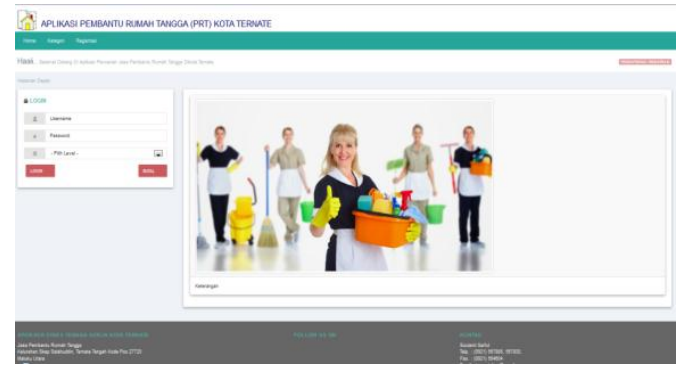

Gambar 23: Halaman Utama

\section{Menu Login}

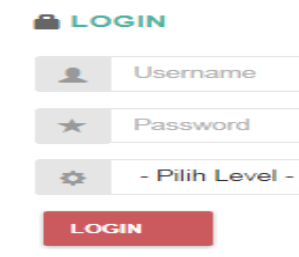

Gambar 24: Menu Login

\section{Menu Admin Halaman Utama}

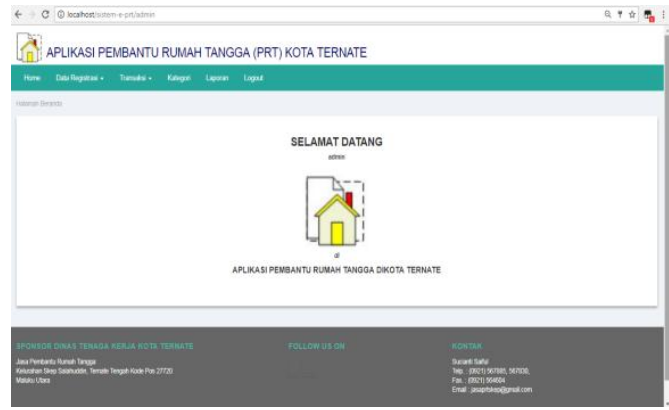

Gambar 25: Halaman Utama Admin

\section{Menu Registrasi Majikan}

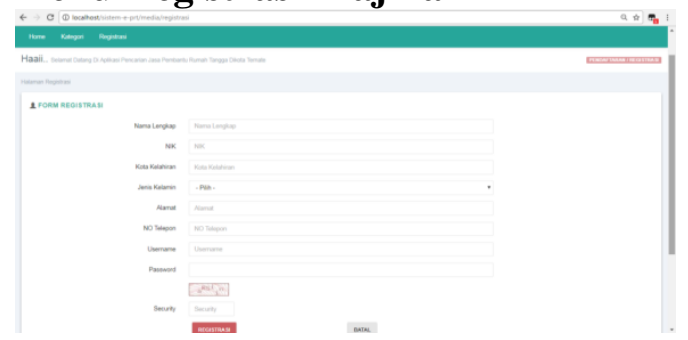

Gambar 26: Menu Registrasi Majikan
Menu Admin Kelola Registrasi Data

\section{Majikan}

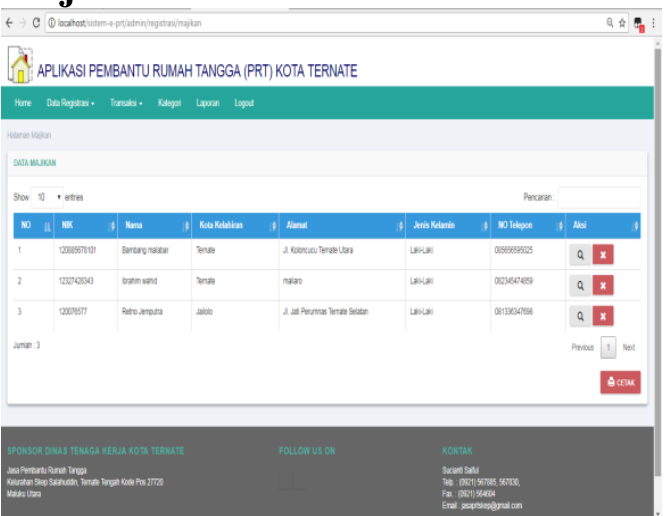

Gambar 27: Menu Admin Kelola

Registrasi Data Majikan

\section{Menu Admin Kelola Kategori}

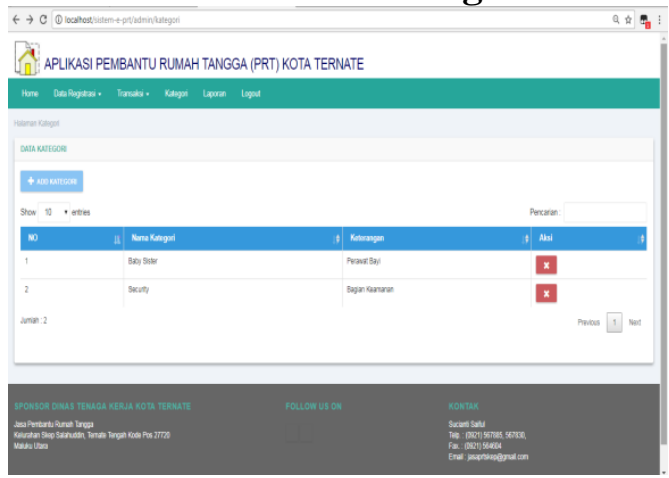

Gambar 28: Menu Admin Kelola Kategori

\section{Menu Admin Kelola Transaksi} Konfirmasi Pemesanan

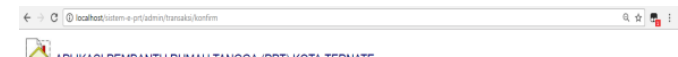

A. APLIKASI PEMBANTU RUMAH TANGGA (PRT) KOTA TERNATE

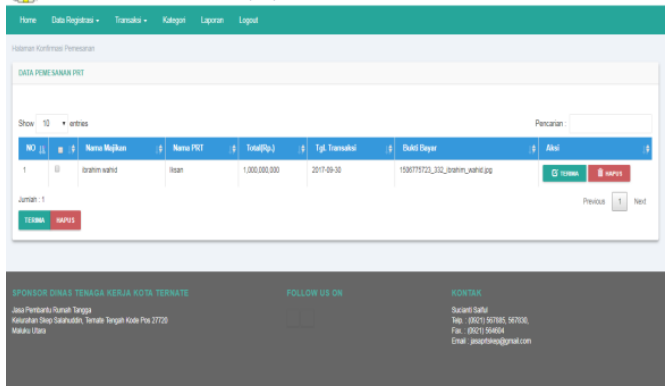

Gambar 29: Menu Admin Kelola

Transaksi Konfirmasi Pemesanan 
Menu Admin Kelola Transaksi List Pembayaran

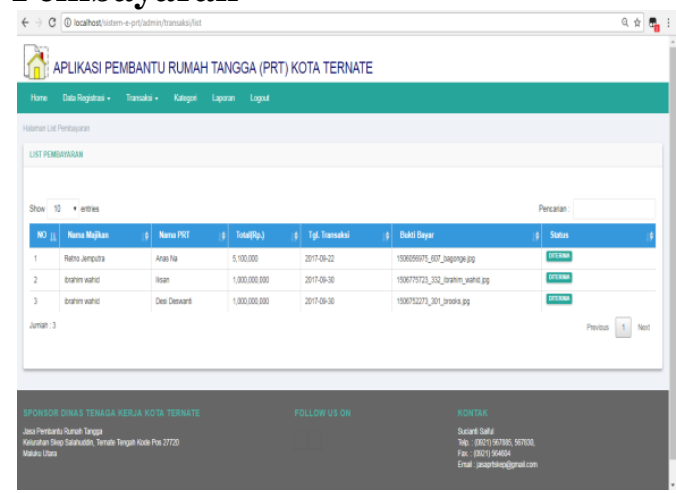

Gambar 30: Menu Admin Kelola

Transaksi List Pembayaran

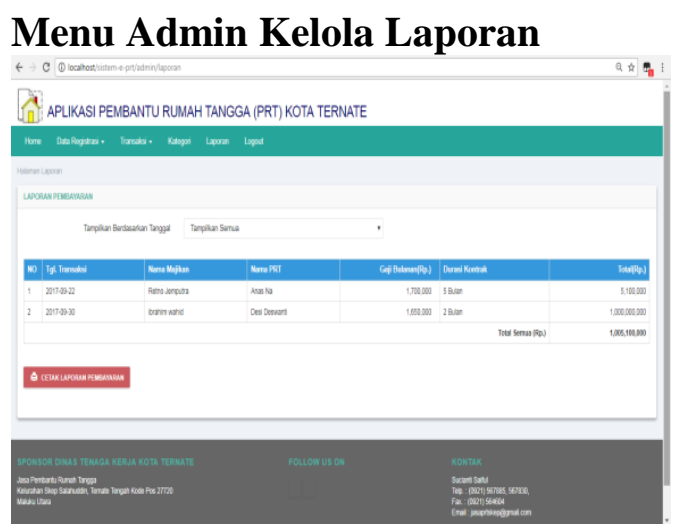

Gambar 31: Menu Admin Kelola Laporan

\section{Menu Admin Cetak Laporan}

Transaksi

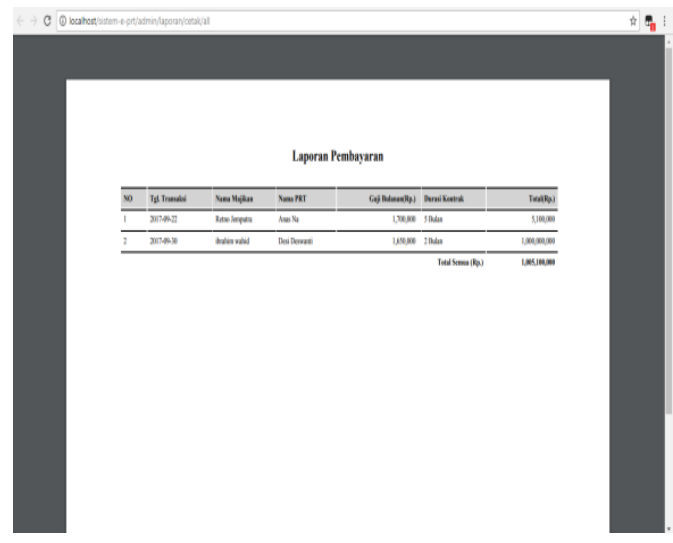

Gambar 32: Menu Admin Cetak Laporan Transaksi
Menu Majikan Melihat Kategori

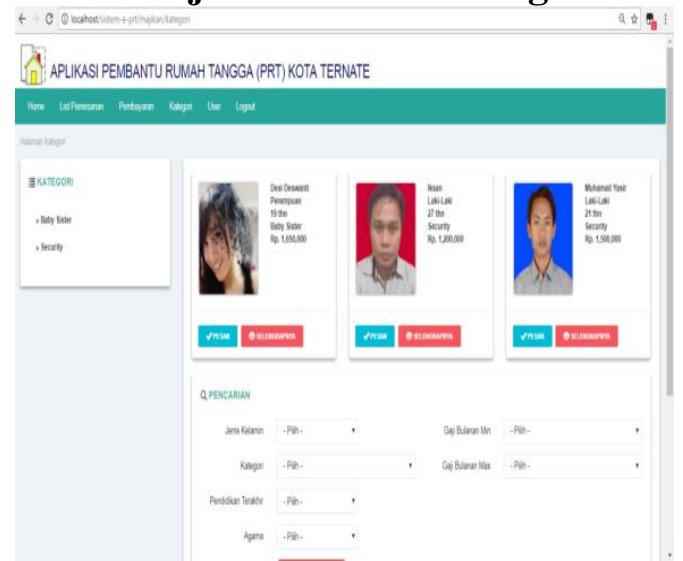

Gambar 33: Menu Majikan Melihat Kategori

\section{Menu Majikan Pesan Prt}

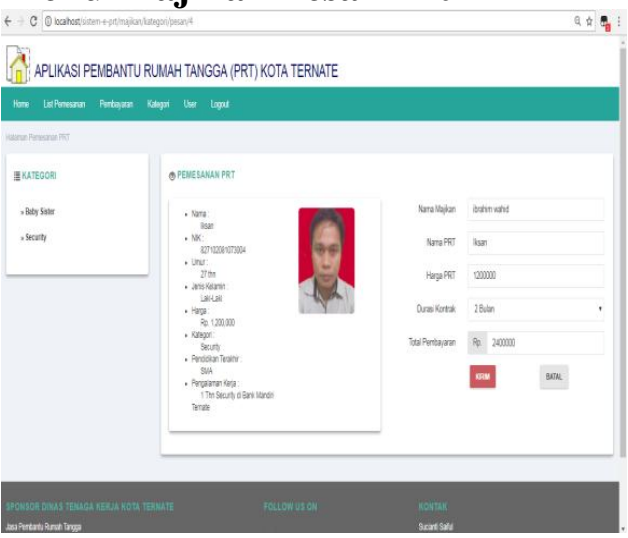

Gambar 34: Menu Majikan Pesan Prt

Menu Lembar Pemberitahuan

\section{Pemesanan Prt Berhasil}

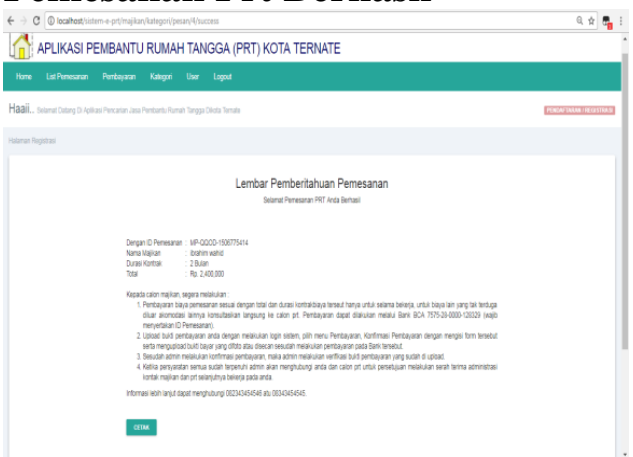

Gambar 35: Menu Lembar

Pemberitahuan

Pemesanan Prt Berhasil 


\section{Menu Majikan Pembayaran (Konfirmasi Pembayaran)}

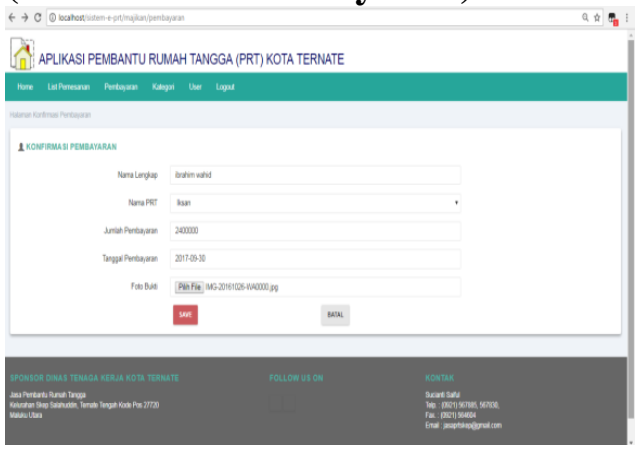

Gambar 36: Menu Majikan

Pembayaran (Konfirmasi Pembayran)

\section{Menu Majikan List Pemesanan (Proses Konfirmasi Admin)}

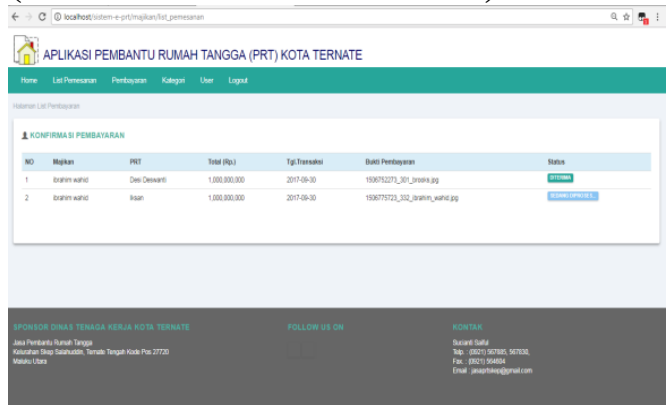

Gambar 37: Menu Majikan List Pemesanan (Proses Konfirmasi Admin)

\section{Pengujian Sistem}

Pengujian Yang di gunakan untuk menguji sistem adalah pengujian blacbox berfokus pada persyaratan fungsional perangkat lunak.

Tabel 1: Uji Blackbox Sistem

\begin{tabular}{|c|c|c|c|c|c|c|}
\hline No & $\begin{array}{l}\text { Antar } \\
\text { Muka }\end{array}$ & ji Coba & $\begin{array}{c}\text { Status } \\
\text { Aplikasi }\end{array}$ & $\begin{array}{l}\text { Skenario } \\
\text { Pengujia } \\
\text { n }\end{array}$ & $\begin{array}{l}\text { Hasil yang } \\
\text { di } \\
\text { harapkan }\end{array}$ & $\begin{array}{l}\text { Hasil } \\
\text { Penguji } \\
\text { an }\end{array}$ \\
\hline \multirow[t]{2}{*}{1} & & \multirow[t]{2}{*}{$\begin{array}{l}\text { Menguj } \\
\text { i proses } \\
\text { login }\end{array}$} & \multirow[t]{2}{*}{$\begin{array}{l}\text { Masuk } \\
\text { menu utama } \\
\text { admin dan } \\
\text { majikan }\end{array}$} & \multirow{2}{*}{$\begin{array}{l}\text { Input } \\
\text { username } \\
\text { dan } \\
\text { password } \\
\text { dan pilih } \\
\text { level }\end{array}$} & $\begin{array}{l}\text { Berhasil } \\
\text { melakukan } \\
\text { validasi }\end{array}$ & \begin{tabular}{|l|} 
Berhasil \\
masuk ke \\
Menu utam
\end{tabular} \\
\hline & & & & & $\begin{array}{l}\text { Gagal } \\
\text { melakukan } \\
\text { validasi }\end{array}$ & $\begin{array}{l}\text { Kembali } \\
\text { ke } \\
\text { tampilan } \\
\text { login }\end{array}$ \\
\hline
\end{tabular}

\begin{tabular}{|c|c|c|c|c|c|c|}
\hline 2 & $\begin{array}{l}\text { Tampila } \\
\text { registrał } \\
\text { majikan }\end{array}$ & $\begin{array}{l}\text { Menguji } \\
\text { Proses } \\
\text { egistras }\end{array}$ & $\begin{array}{l}\text { Tampilan } \\
\text { registrasi } \\
\text { terbuka }\end{array}$ & $\begin{array}{l}\text { Masukan } \\
\text { data-data } \\
\text { pribadi }\end{array}$ & $\begin{array}{l}\text { Menu yang } \\
\text { dipilih dapat } \\
\text { membuka } \\
\text { halaman }\end{array}$ & $\begin{array}{l}\text { Menu yang } \\
\text { dipilih } \\
\text { dapat } \\
\text { membuka } \\
\text { halaman }\end{array}$ \\
\hline 3 & $\begin{array}{l}\text { Tampil } \\
\mathrm{an} \\
\text { Itama } \\
\text { dmin } \\
\text { lan } \\
\text { najikan }\end{array}$ & $\begin{array}{l}\text { Menguj } \\
\text { i semua } \\
\text { menu } \\
\text { yang } \\
\text { terdapa } \\
\text { t pada } \\
\text { halama } \\
\text { n web }\end{array}$ & $\begin{array}{l}\text { Tampilan } \\
\text { halaman } \\
\text { web sudah } \\
\text { terbuka }\end{array}$ & $\begin{array}{l}\text { Klik menu } \\
\text { yang } \\
\text { tersedia }\end{array}$ & $\begin{array}{l}\text { Menu yang } \\
\text { dipilih dapat } \\
\text { membuka } \\
\text { halaman }\end{array}$ & \begin{tabular}{|l|} 
Menu yan \\
dipilih \\
dapat \\
membuka \\
halaman
\end{tabular} \\
\hline 4 & \begin{tabular}{|l|} 
Tampil \\
an \\
Kelola \\
Ketegor \\
prt
\end{tabular} & $\begin{array}{l}\text { Menguji } \\
\text { Intuk } \\
\text { menamb } \\
\text { kategori }\end{array}$ & $\begin{array}{l}\text { Masuk pada } \\
\text { add kategori }\end{array}$ & $\begin{array}{l}\text { Masukkan } \\
\text { nama dan } \\
\text { keterangan } \\
\text { kategori }\end{array}$ & $\begin{array}{l}\text { Menu yang } \\
\text { dipilih dapat } \\
\text { menambah } \\
\text { kategori prt }\end{array}$ & $\begin{array}{l}\text { Menu yan } \\
\text { dipilih } \\
\text { dapat } \\
\text { menambah } \\
\text { kategori } \\
\text { prt } \\
\end{array}$ \\
\hline 5 & $\begin{array}{l}\text { Tampi } \\
\text { an } \\
\text { kelola } \\
\text { egistr } \\
\text { asi } \\
\text { lata } \\
\text { prt }\end{array}$ & $\begin{array}{l}\text { Menguj } \\
\text { i untuk } \\
\text { menam } \\
\text { bah prt }\end{array}$ & \begin{tabular}{|l} 
Masuk \\
menu data \\
registrasi prt
\end{tabular} & $\begin{array}{l}\text { Masukan } \\
\text { data } \\
\text { pembantu }\end{array}$ & $\begin{array}{l}\text { Menu yang } \\
\text { dipilih dapat } \\
\text { menambah da } \\
\text { prt }\end{array}$ & $\begin{array}{l}\text { Menu } \\
\text { yang } \\
\text { dipilih } \\
\text { dapat } \\
\text { menamb } \\
\text { ah data } \\
\text { prt }\end{array}$ \\
\hline 6 & $\begin{array}{l}\text { Tampila } \\
\text { n List } \\
\text { Pemesan } \\
\text { an }\end{array}$ & $\begin{array}{l}\text { Menguj } \\
\text { Proses } \\
\text { Pemesa } \\
\text { nan }\end{array}$ & $\begin{array}{l}\text { Tampilan } \\
\text { Pemesanan }\end{array}$ & $\begin{array}{l}\text { Pemesana } \\
\text { n berhasil }\end{array}$ & $\begin{array}{l}\text { Pemberitahuar } \\
\text { pemesanan } \\
\text { berhasil }\end{array}$ & $\begin{array}{l}\text { Pemberitah } \\
\text { uan } \\
\text { pemesanan } \\
\text { berhasil }\end{array}$ \\
\hline 7 & $\begin{array}{l}\text { Tampila } \\
\text { Transak } \\
\text { Pembay } \\
\text { an }\end{array}$ & $\begin{array}{l}\text { Menguj } \\
\text { Proses } \\
\text { Transak } \\
\text { Pemesa } \\
\text { n }\end{array}$ & $\begin{array}{l}\text { Tampilan } \\
\text { Transaksi } \\
\text { Pemesanan }\end{array}$ & $\begin{array}{l}\text { Input data } \\
\text { pembayara } \\
\text { n lalu klik } \\
\text { save }\end{array}$ & $\begin{array}{l}\text { Berhasil } \\
\text { Disimpan }\end{array}$ & $\begin{array}{l}\text { Berhasil } \\
\text { disimpan }\end{array}$ \\
\hline 8 & $\begin{array}{l}\text { Tampila } \\
\text { Laporan } \\
\text { Pembay } \\
\text { an }\end{array}$ & $\begin{array}{l}\text { Menguj } \\
\text { Proses } \\
\text { Input } \\
\text { Pembay } \\
\text { an }\end{array}$ & $\begin{array}{l}\text { Tampilan } \\
\text { Hasil Input } \\
\text { Pembayaran }\end{array}$ & $\begin{array}{l}\text { Hasil data } \\
\text { Pembayara } \\
\text { yang akan } \\
\text { cetak }\end{array}$ & $\begin{array}{l}\text { Berhasil di } \\
\text { acetak }\end{array}$ & $\begin{array}{l}\text { Berhas } \\
\text { il di } \\
\text { cetak }\end{array}$ \\
\hline
\end{tabular}

\section{KESIMPULAN}

Berdasarkan Pembahasan yang telah dilakukan, maka dapat ditarik beberapa kesimpulan tentang pembuatan aplikasi web pencarian jasa pembantu rumah tangga (PRT) Di Kota Ternate diantaranya sebagai Berikut : 1) Dengan adanya aplikasi ini dapat membantu mempercepat Pencarian jasa pembantu dan menyampaikan data yang akurat, sehingga informasi yang dihasilkan sesuai dengan apa yang diharapkan dan yang benar-benar terjadi sesuai keadaan. 2) Dengan dibangunnya aplikasi pencarian jasa pembantu rumah tangga yang 
terintegrasi dengan database diharapkan dapat mempercepat proses pencarian baik data customer, data pembantu maupun data transaksi yang di lakukan secara manual. 3) aplikasi ini memberikan informasi mengenai data seputar pembantu rumah tangga, dan majikan yang membutuhkan pekerja. Hal ini adalah untuk membuka wawasan baik masyarakat yang berminat untuk mencari pembantu rumah tangga ataupun pihak lain yang membutuhkan.

Berdasarkan

kesimpulan tersebut maka diajukan saran sebagai berikut :

1) diharapkan Aplikasi yang telah dibangun agar dapat dikembangkan di masa yang akan datang seiring dengan kemajuan teknologi formal.

Pembangunan aplikasi ini masih bersifat independent terhadap sistem informasi

lain. Oleh karena itu, perlu dilakukan pengembangan lebih lanjut agar aplikasi pencarian jasa pembantu rumah tangga ini dapat terintegrasi dengan sistem informasi lain. 3) Proses pembayaran seharusnya dapat dilakukan secara online, sehingga untuk konfirmasi pembayaran dapat diakses lebih cepat dan aman dan bisa menjadi website yang benar-benar bisa diakses secara luas oleh masyarakat, diharapkan bisa memberikan informasi yang jelas dan akurat.

\section{DAFTAR PUSTAKA}

Ian Sommerville. 2003, Software Engineering (Rekayasa Perangkat Lunak) / Ian Sommerville;
Terjemahan Edisi 6. Jakarta. Erlangga.

Soenyoto, S. 2008. Pekerjaan Dalam Dimensi Waktu. Yogyakarta. Andi. Raharjo, B. (2011). Belajar Otodidak Membuat Database Menggunakan $M y S Q L$. Bandung. Informatika.

Supardi, Y. 2011. PHP dan MySQL. Jakarta. Ardikom Lautan Ilmu.

Saputra, A. 2011. Trik dan Solusi Jitu Pemrograman PHP. Jakarta: IKAPI Yakub 2012. Pengantar Sistem Informasi. Yogyakarta. Graha Ilmu. Ardhana 2012. Manajemen Sumber Daya Manusia. Yogyakarta. Graha Ilmu

Kurniawan, B. (2012). Desain Web Praktis dengan CSS. Jakarta. Elex Media Komputindo.

M. Leo Agung, 2012. Element 9 Untuk Pemula. Yogyakarta. Andi.

Prasetio, A. 2012. Buku Pintar Pemrograman Web. Jakarta Selatan: Mediakita.

Panji, Akbar. (2012). Perancangan Sistem Informasi Penjualan Pada Restoran Tulang Jambal Bandung. Unikom. Bandung.

Roger, S. Pressman, Ph.D., 2012, Rekayasa Perangkat Lunak (Pendekatan Praktisi) Edisi 7. Buku 1, Yogyakarta. Andi.

Strauss, Judy dan Frost, Raymond. 2012. E-Marketing edisi internasional ke 6 . London. Pearson.

Sidik, B. (2012). Pemrograman Web dengan PHP. Solo. Santika Kencana.

Sutarman, 2012. Pengantar Teknologi Informasi. Jakarta. Bumi Aksara. Sugiyono, 2012. Memahami Penelitian Kualitatif. Bandung. ALFABETA.

Strauss, J., \& Frost, R. 2012. EMarketing. Edisi Internasional ke 6. London. Pearson 
Sibero, A. F.K. 2012. Kitab Suci Web Programing. Jakarta. Mediakom.

Sutabri, T. 2012. Analisis Sistem Informasi. Yogyakarta. Andi.

Satzinger, W, J, Jackson, B, R., \& Burd, D, S. 2012. Systems Analysis and Design In A Changing World. Boston: Cengage Learning.

Subhan, M. 2012. Analisa Perancangan Sistem. Jakarta. Lentera Ilmu Cendekia.

A., S., Rosa \& Shalahuddin, M. (2013). Rekayasa Perangkat Lunak Terstruktur Dan Berorientasi Objek. Bandung. Informatika.

Asropudin, P. 2013. Kamus Teknologi Informasi. Bandung. Titian Ilmu

Al-Bahra, B. L. (2013). Analisis dan Desain Sistem Informasi. Yogyakarta. Graha Ilmu.

Hartono, B. 2013. Sistem Informasi Manajemen Berbasis Komputer. Jakarta. Rineka Cipta.

Jogiyanto. 2013. Analisis \& Desain Sistem Informasi: Pendekatan tertruktur teori dan praktik aplikasi bisnis. Yogyakarta. Andi Offset.

Saputra, A. (2013). Membangun Aplikasi Bioskop dan SMS untuk Panduan Skripsi, PT Elex Media Komputindo. Jakarta.

Sibero, A. F.K. 2013. Web Programming Power Pack. Yogyakarta: Mediakom.

Taufiq R. (2013). Sistem Informasi Manajemen. Konsep Dasar, Analisis dan Metode Pengembangan. Yogyakarta: Graha Ilmu.

Widijanuarto 2014. Jurus Kilat Membuat Jaringan Komputer. Jakarta: Dunia Komputer

Buana, I Komang. S. 2014. Jago Pemrograman PHP. Yogyakarta: Penerbit Dunia Komputer.
Muharto \& Ambarita, A. 2016. Metode Penelitian Sistem Informasi: Mengatasi Kesulitan Mahasiswa Dalam Menyusun Proposal Penelitian. Deepublish. Yogyakarta.

Considine, Brett., Parkes, Alison., Olesen, Karin., Blount, Yvette, Speer, Derek. Th Accounting Information Systems: Understanding Business Processes (4 edition). New York: John Wiley \& Sons, Inc, 2012.

Nidhra, Srinivas dan Dondeti, Jagruthi. 2012: Black Box And White Box Testing Techniques -A Literature Review, International Journal of Embedded Systems and Applications (IJESA) Vol. 2, No. 2, pp 8-9.

Kartini., Fahnun, B. U. \& Pratiwi, D. 2013. Perancangan Sistem Informasi Pemesanan Tiket Konser Musik Online Berbasis Lokasi. Yogyakarta: Prosiding Seminar Nasional Teknologi Informasi Dan Multimedia (Semnasteknomedia) 2013. STMIK AMIKOM Yogyakarta 19 Januari 2013

Vivin Ambar, Arisandy Ambarita, Sistem Informasi Pengolahan Data Kelulusan Siswa Non-Formal Berbasis Web Pada Dinas Pendidikan Nasional Kota Ternate, IJIS - Indonesian Journal On Information System, Volume 2 Nomor 1 April Tahun 2017, ISSN 2548-6438

Ilmi, H. Z., \& Qoiriah, A. (2016). Perancangan Sistem Informasi Pencarian Asisten Rumah Tangga Berbasis Web. Jurnal Manajemen Informatika, 6 (1). 